Strategic Environmental Assessment System
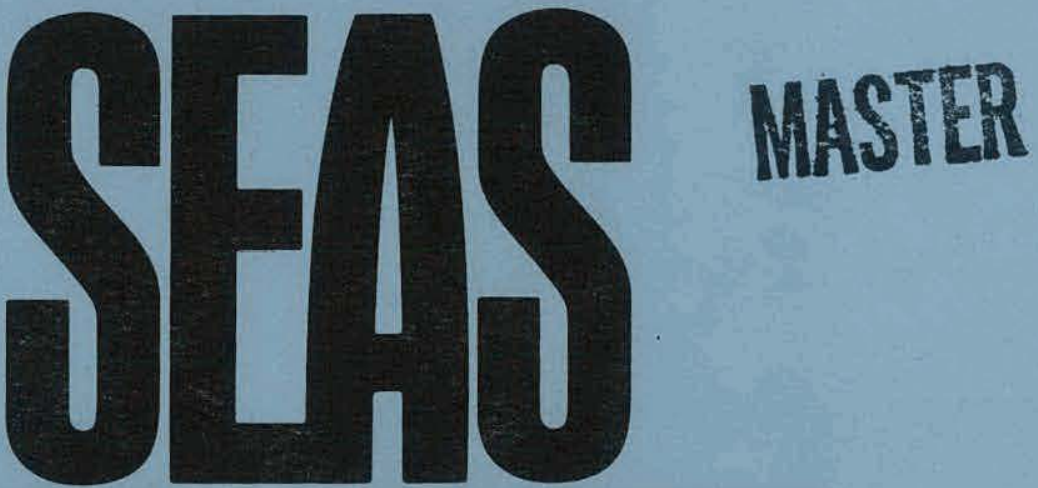

Introduction to the Strategic Environmental Assessment System

\author{
Prepared for: \\ U.S. Department of Energy \\ Assistant Secretary for Environment \\ Office of Environmental Assessment \\ Regulatory Analysis Division
}




\section{DISCLAIMER}

This report was prepared as an account of work sponsored by an agency of the United States Government. Neither the United States Government nor any agency Thereof, nor any of their employees, makes any warranty, express or implied, or assumes any legal liability or responsibility for the accuracy, completeness, or usefulness of any information, apparatus, product, or process disclosed, or represents that its use would not infringe privately owned rights. Reference herein to any specific commercial product, process, or service by trade name, trademark, manufacturer, or otherwise does not necessarily constitute or imply its endorsement, recommendation, or favoring by the United States Government or any agency thereof. The views and opinions of authors expressed herein do not necessarily state or reflect those of the United States Government or any agency thereof. 


\section{DISCLAIMER}

Portions of this document may be illegible in electronic image products. Images are produced from the best available original document. 


\section{NOTICE}

This report was prepared to document work sponsored by the United States Government. Neither the United States nor its agent, the United States Department of Energy, nor any Federal employees, nor any of their contractors, subcontractors or their employees, makes any warranty, express or implied, or assumes any legal liability or responsibility for the accuracy, completeness, or usefulness of any information, apparatus, product or process disclosed, or represents that its use would not infringe privately owned rights.

Reference to a company or product name does not imply approval or recommendation of the product by The MITRE Corporation/Metrek Division or the U.S. Department of Energy to the exclusion of others that may be suitable.

Printed in the United States of America Available from

National Technical Information Service

U.S. Department of Commerce 5285 Port Royal Road Springfield, VA. 22161

NTIS price codes

Printed copy: A04 Microfiche copy: A01 


\title{
Introduction to the Strategic Environmental Assessment System
}

\author{
Marc Narkus-Kramer \\ Kathy Rebibo \\ Beth Borko \\ Nazir Dossani (CONSAD Research Corp.) \\ Roberta Hutchison \\ Betsy Smith \\ Andrea Weiss
}

October 1980

MTR-80W115

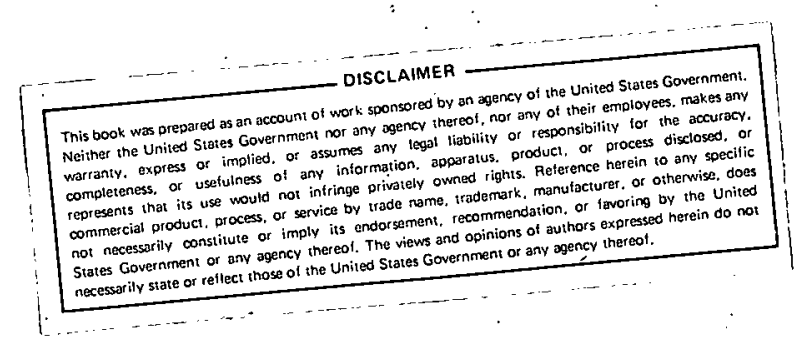

Prepared for:

U.S. Department of Energy

Assistant Secretary for Environment

Office of Environmental Assessment

Regulatory Analysis Division

Arthur Roemer DOE Project Manager

Contract No.: DE-AC02-79EV10092

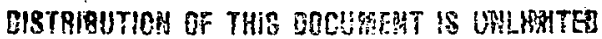

The MITRE Corporation

Metrek Division

18

1820 Dolley Madison Boulevard

McLean, Virginia 22102 
THIS PAGE

\section{WAS INTENTIONALLY LEFT BLANK}




\begin{abstract}
The Strategic Environmental Assessment System (SEAS) is an integrated set of computer programs and associated data bases used to project and anlyze national and regional environmental trends. The two major users of SEAS are the Department of Energy (DOE) and the Environmental Protection Agency (EPA). These agencies use SEAS to project the likely emissions of key pollutants given specific assumptions concerning environmental regulations, future levels of energy supply, and economic activity. This introduction to SEAS discusses how the model has been used in specific applications, the general model structure, the data base, and the available documentation.
\end{abstract}


FOREWORD

In the Fall of 1979 a series of Working Papers were begun which would provide the initial introduction to the various modules of the Strategic Environmental Assessment System (SEAS). In the past year most reports in the series have been published. This was initially intended to be a fifteen volume paper. Some of the reports have been published under other document numbers, some have been dropped from the series and three have not yet been published. The current status of the series is as follows:

1. Introduction to the Strategic Environmental Assessment System, MTR-80W115, October 1980.

2. SEAS Training Session on Electric Utilities Module, WP-79w00617, Volume, II, The MITRE Corporation, November 1979.

3. SEAS Training Session on Coal Mining Module, WP-79W00617, Volume III, The MITRE Corporation and CONSAD Research Corporation, November 1979.

4. SEAS Training Session on Regionalization, WP-79W00617, Volume IV, The MITRE Corporation, December 1979.

5. Introduction to the Industrial Fuel Use Module of SEAS, The MITRE Corporation, WP-79W00617.

6. Introduction to the Energy Network Simulator, to be published.

7. Introduction to the SEAS Economic Modules, to be published.

8. SEAS Documentation: The Energy Investment Feedback Module, CONSAD Research Corporation, October 1979.

9. Introduction to the Residual Generation Module of SEAS, WP-79W00617, Volume IX, the MITRE Corporation, March 1980.

10. SEAS Documentation: The Indirect Residuals Module, CONSAD Research Corporation, December 1979.

11. Introduction to the SEAS Transporation Module, to be published. These reports can be obtained from the SEAS MITRE Library.

Kathy K. Rebibo

30 Ocotober 1980 
LIST OF ILLUSTRATIONS

vi

LIST OF TABLES

$v i$

INTRODUCTION

1

Model Overview

2

Available Documentation

7

APPLICATION OF SEAS

Comprehensive Assessments

11

Issue Specific Studies

HOW SEAS WORKS

23

Energy Modules

25

Economic Modules

36

Regionalization Module

44

Environimental Modules

47

THE SEAS DATA BASE

51

Types of SEAS Data

52

Selected Data Sources and Evaluation

56

REFERENCES

59

GLOSSARY OF ACRONYMS

63

DOE FOR IR-426

65 


\section{LIST OF ILLUSTRATIONS}

Figure Number

Page

1

Simplified SEAS Flow Diagram

3

2

Emission Trends from SEAS for NEIP No. 1

14

3

Regional Projections

15

4

Use of SEAS in Region VI Briefing

17

5

The Basic SEAS Modules

26

6

The Energy and Economic Modules

37

7

The Relationship of REGION to the Energy

and Economic Modules

45

8

SEAS F1ow Diagram

48

\section{LIST OF TABLES}

Table Number

$\underline{\text { Page }}$

I

Major Environmental Factors Projected by SEAS

II References to Introductory Module

Documentation

III Major National Envirormental Trends

from the NEIP No. 1

IV

New Source Performance Standards (NSPS)

Options 


\section{INTRODUCTION}

The Strategic Environmental Assessment System (SEAS) is a computer-based tool that is used for assessing alternative environmental and energy strategies. The primary purpose of the model is to project the emissions of key pollutants given a specific scenario of input assumptions. These assumptions concern the stringency of enviromental regulations, future levels of energy supply, and overall economic growth (GNP). Projections can be provided for the nation and many regional levels including Federal Regions, States, and Air Quality Control Regions.

SEAS was conceived in 1972 in the Environmental Studies Division of the Environmental Protection Agency. The model was first used in 1974 to provide input to the Councll on Environmental Quality Annual Report and to the Cost of Clean Environment Report. SEAS was adopted by the Department of Energy* in 1977 and modified for use as a comprehensive planning tool in the Office of Environmental Health and Safety.

Currently the model is supported by both DOE and EPA. The Regulatory Analysis Division ( $R A D$ ) within DOE's Office of Environmental Assessment under the Assistant Secretary. for the Environment is now a sponsor. At EPA, SEAS is sponsored by the Office of Energy Minerals

\footnotetext{
*The Department of Energy at that time was the Energy Research and Development Administration (ERDA).
} 
and Industry and the Office of Research and Development. SEAS has been used by these agencies in many applications including:

- Assessment of the environmental impacts associated with the National Energy Plan [Annual Environmental Analysis..., 1977; Environmental Trends..., 1979]"

- Preparation of the Annual Environmental Assessment Reports [Annual Environmental Analysis..., 1977; Annual Environmental Analysis..., 1979]

- Support to EPA's Environmental Outlook Report for 1979 and 1980. [Draft Environmental Outlook..., 1979]

- A technology assessment of solar energy. (TASE) [Carlson, 1980]

- Preparation of the annual National Environmental Impact Projections [National Environmental Impact Projection No. 1, 1978; National Environmental Impact Projection II, 1980]

- Support of the Ohio River Basin Study [Gerson, 1980]

Some of these applications are discussed later in this paper. MODEL OVERVIEW

SEAS is comprised of many integrated computer programs and an extensive data base. To help understand and manage the system, there are documentation and management control procedures. SEAS is used to simulate, within a consistent framework, the interactions between energy activities, economic activities and the generation of environmental pollutants. This is done at various levels of regional detail. Sets of programs and data which serve a particular function in the simulation (e.g., the regionalization or the pollution generation) are called modules. Figure 1 is a simplified flow diagram of the SEAS system showing the important modules.

\footnotetext{
${ }^{*}$ Brackets refer to entries in the References section.
} 


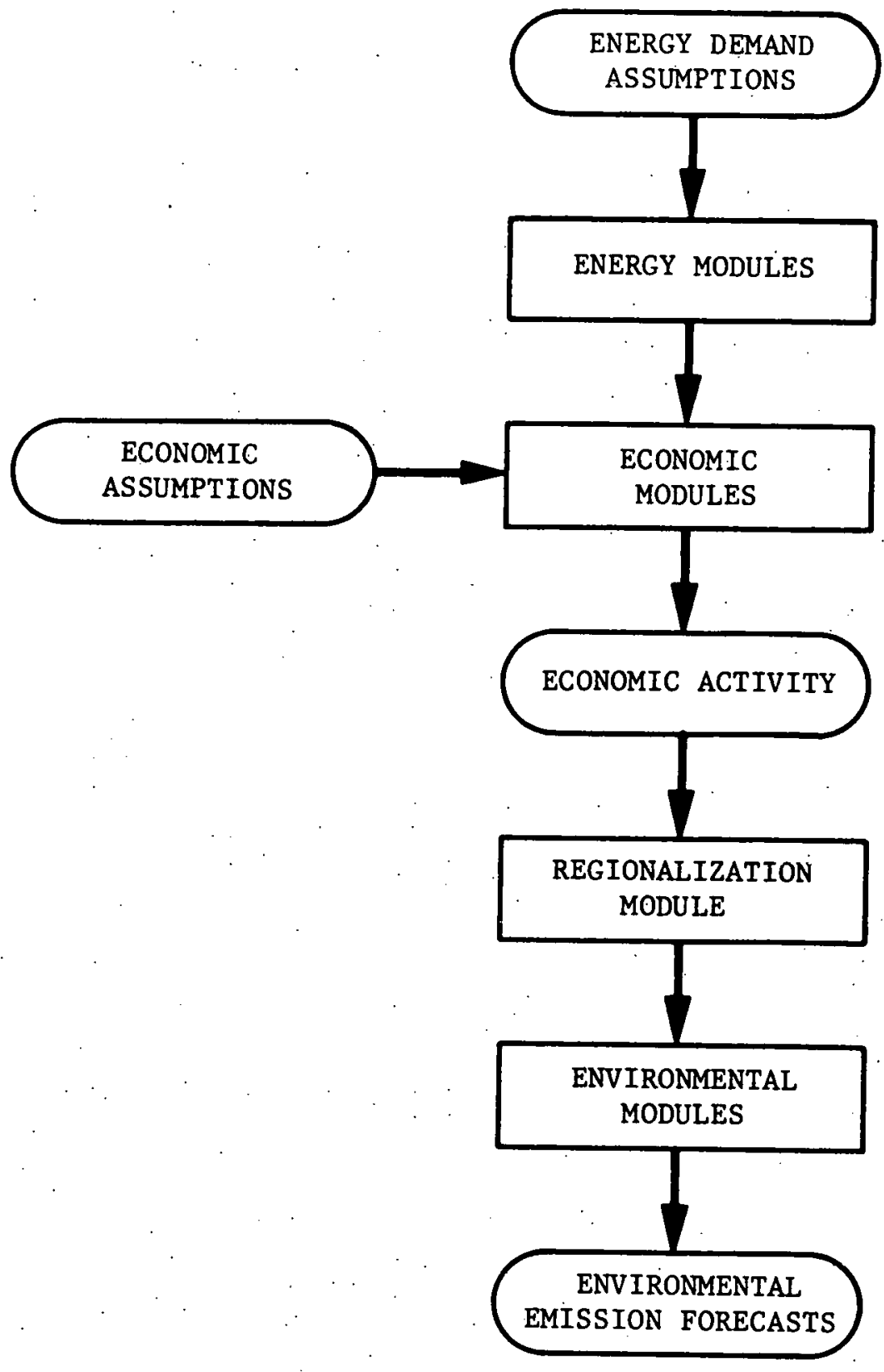

FIGURE 1

SIMPLIFIED SEAS FLOW DIAGRAM 
Use of the model begins with a definition of an energy future or scenario. This is often taken from an external energy model. The SEAS energy modules take energy supply and demand assumptions defined by the scenario and disaggregate them to a regional and technological detail necessary for accurate pollution forecasts. Based on given assumptions of economic growth (GNP) and unemployment, the economic modules project detailed consumer and industrial activity consistent with the energy scenario. (Over 500 activities are projected in SEAS, including over 40 chemical products and three major steel producing processes). These activities are regionalized and input into the enviromental modules. The environmental modules in turn compute pollution emissions and selected resource requirements that can be expected from the industrial activity in each region. The major environmental pollutants and resource requirements in SEAS are shown in Table I. Additional categories of pollutants can also be handled; however, the data for many of these pollutants are out of date or incomplete and are not used in current assessments. These categories include trace metals, metallic inorganics, organic compounds, pesticides, radionucleids, nutrients and several categories of wastes.*

\footnotetext{
*A complete 1ist of pollutants and their definitions can be found in Taxonomy Manual and User's Guide for SEAS Environmental Residuals, [Bodden, 1980]. The report, Guidance for Interpretation of Projections from the May 1980 Reference System, [McBrien, 1980] discusses which pollutants have been certified as comparable to other data sources and are available for general use.
} 
TABLE I

MAJOR ENVIRONMENTAL FACTORS PROJECTED BY SEAS

AIR
- particulates
- sulfur oxide
- nitrogen oxide
- carbon monoxide
- carbon dioxide
- hydrocarbons

WATER

- biochemical oxygen demand

- total suspended solids

- total dissolved solids

- oil and grease

SOLID WASTES

- ash and char

- sludge from sulfur dioxide removal

- other industrial sludges"

WATER CONSUMPTION

LAND USE

OCCUPATIONAL SAFETY

LABOR REQUIREMENTS 


\section{Model Inputs}

There are two major inputs to the model and several variables commonly manipulated for specific studies. The first major input is the future mix of energy supply and demand. Different energy mixes mean different fuel use, as well as a different use of technologies. These energy mixes are generally obtained from models external to SEAS. The second major input is the overall growth of the economy which is specified in terms of the projected growth of GNP or a productivity rate and unemployment rate.

Other variables can be changed to examine specific issues. In SEAS, it is usually assumed that all environmental regulations will be met by 1985. However, for specific analysis these assumptions can be relaxed and compliance becomes an input to the model. The rate of technological substitution is generally fixed; however, it too can be varied for special analyses. Technological substitution is defined in SEAS as either the composition of inputs into a product or competing ways of producing a product. An example of the former is the substitution of aluminum for steel in automobile manufacturing, while an example of the latter is substitution of the basic oxygen furnace for the open hearth furnace in making steel.

Mode1 Outputs

SEAS provides outputs of economic and energy activity by region for years between 1975 and 2000. It also projects emissions and specific resource/safety information, on a regional level by industry. The regions which are most commonly used by SEAS are Federal 
Regions, States, Air Quality Control Regions (AQCR's), Standard Metropolitan Statistical Areas (SMSA's), Aggregated Sub Areas (ASA's) and Bureau of Economic Analysis Areas (BEA's). SEAS has report programs which display this information and allow the user to compare results from two scenarios. The year, sector, pollutant and regional dimension can result in several million numbers for output. Because of this, SEAS has several reports which aggregate the results. AVAILABLE DOCUMENTATION

Documentation of the SEAS model and data base is described in $\mathrm{A}$ Guide to SEAS Documentation, [TenEyck, 1980] - Th1s report contains a one page citation to each entry in the SEAS Documentation Package. The package contains over 80 reports and ls organized into six sections: System Overview, Module Descriptions, Data; Operations, Software, and Malntenance. The Guide also contalns a listing of documents that are not included in the documentation package but are relevant to SEAS, such as reports on analyses using SEAS.

Several documents are of special interest to those first learning SEAS. Table II references the best initial introductions to each SEAS module. Additional reports of interest are:

- the "guidance document" [McBrien, 1980] which discusses which pollutants have been reviewed and are of general use without further data development,

- the Names and Definitions Manual [Metzger, 1980] which contalns computerlzed lists of codes for SEAS sectors and subsectors, pollutants and regions, as well as units and other information, 
TABLE II

REFERENCES TO INTRODUCTORY MODULE DOCUMENTATION

MODULE NAME

REFERENCE

Electric Utilities Module (EUM)

Hand, 1979; Weiss, 1980

Industrial Fuel Use Module (IFUM)

Preston, 1980

Coal Mining Module (CMM)

Weygendt, 1979

Energy System Network Simulator (ESNS)

Placet, 1979

Interindustry Input/Output Model (INFORUM)

Almon, 1974; House, 1977

Sector Disaggregation (INSIDE)

House, 1977; Gerson, 1979

Pollution Abatement (ABATE)

House, 1977

Energy Investment Module (INVEST)

Adler, 1979

Regional Disaggregation Module (REGION)

Hand, 1979

Residual Generation Module (RESGEN)

Tawari, 1980

Transportation Module (TRANS)

Shapanka, 1979 
- Scenario Run Control Procedures [Metzger, 1980] which gives the management control procedures for using SEAS,

- Description of SEAS reports [Anderson, 1978] which describes SEAS output reports and the options: available. These are reports in addition to the summary report package which is usually requested. 
THIS PAGE

\section{WAS INTENTIONALLY \\ LEFT BLANK}




\section{APPLICATIONS OF SEAS}

SEAS can be applied to either comprehensive or issue specific analyses. Comprehensive assessments are commonly used to support long range program planning and generally incorporate many policy assumptions. Issue specific assessments aid in choosing the best policy from a number of competing policy options. When the model is applied in a comprehensive mode, a complete and consistent set of energy, economic and environmental assumptions are entered into the model. For issue specific analysis, variables related to specific policy issues, such as alternative proposals for controlling emissions, may only need to be varied. Examples of these two types of applications are discussed below. COMPREHENSIVE ASSESSMENTS National Environmental Impact Projection

The annual National Environmental Impact Projection is performed to ensure that DOE energy programs will be compatible with the nation's environmental goals. This study is done for DOE's Office of Environmental Assessment. Its purpose is to assess the environmental and economic impacts expected from energy projections provided by the Energy Information Administration (EIA) of DOE.

EIA projects energy use out to the year 1995 using the MEFS* model. This forecast scenario is consistent with given assumptions

\footnotetext{
*MEFS, Midterm Energy Forecasing System, is a successor to the PIES model.
} 
on world oil price and the current energy policy. SEAS is then used to project pollution emissions from energy and non-energy sources likely to occur under the EIA energy forecast. The SEAS outputs are analyzed by the project team to provide the basis for the annual projections of enviromental trends.

The publication National Environmental Impact Projection No. 1 [National Environmental..., 1978] is the final report of the first NEIP. It identifies and analyzes projected trends in the release of specific pollutants from 1975 to 1990 . The major results of this study are summarized in Table III. Figures 2 and 3, reproduced from this document, illustrate the type of national and regional trends that can be developed from SEAS. Figure 2 shows that air pollutant emissions for which regulations apply are expected to decrease. Figure 3 indicates where increases in sulfur doxide emissions can be expected in 1990.

Environmental Outlook

The Environmental Outlook is a comprehensive document prepared annually by the Office of Research and Development within EPA. The purpose behind the document is to ensure that research and development planning takes into account long term trends. SEAS is used to provide information on major trends in air, water and solid waste pollutant discharges.

For Environmental Outlook 1980 [Draft Environmental Outlook..., 1979] the focus was on the environmental implications of future 
TABLE III

MAJOR NATIONAL ENVIRONMENTAL TRENDS

FROM THE NEIP NO. 1

AIR POLLUTION

- Sulfur oxide emissions remain essentially the same as 1.975

- Hydrocarbon and carbon monoxide emissions decrease due to controls on auto emission

- Nitrogen oxide emissions increase due to fossil fuel combustion

- Total suspended particulate emissions decrease due to the increased use of electrostatic precipitators

WATER POLLUTION

- Among major water pollutants, only total dissolved solids (TDS) and nitrogen discharges increase

- Energy and combustion contributions are generally small, with the following exceptions:

- utilities contribute significantly to TDS

- oil imports contribute significantly to oil and grease in 1970

WATER CONSUMPTION

- Significant increases are expected among energy (primarily utilities) and manufacturing sectors by 1990

SOLID WASTE

- Very large volumes of sludge and ash result from increased coal combustion and the imposition of stringent standards on existing facilities. 


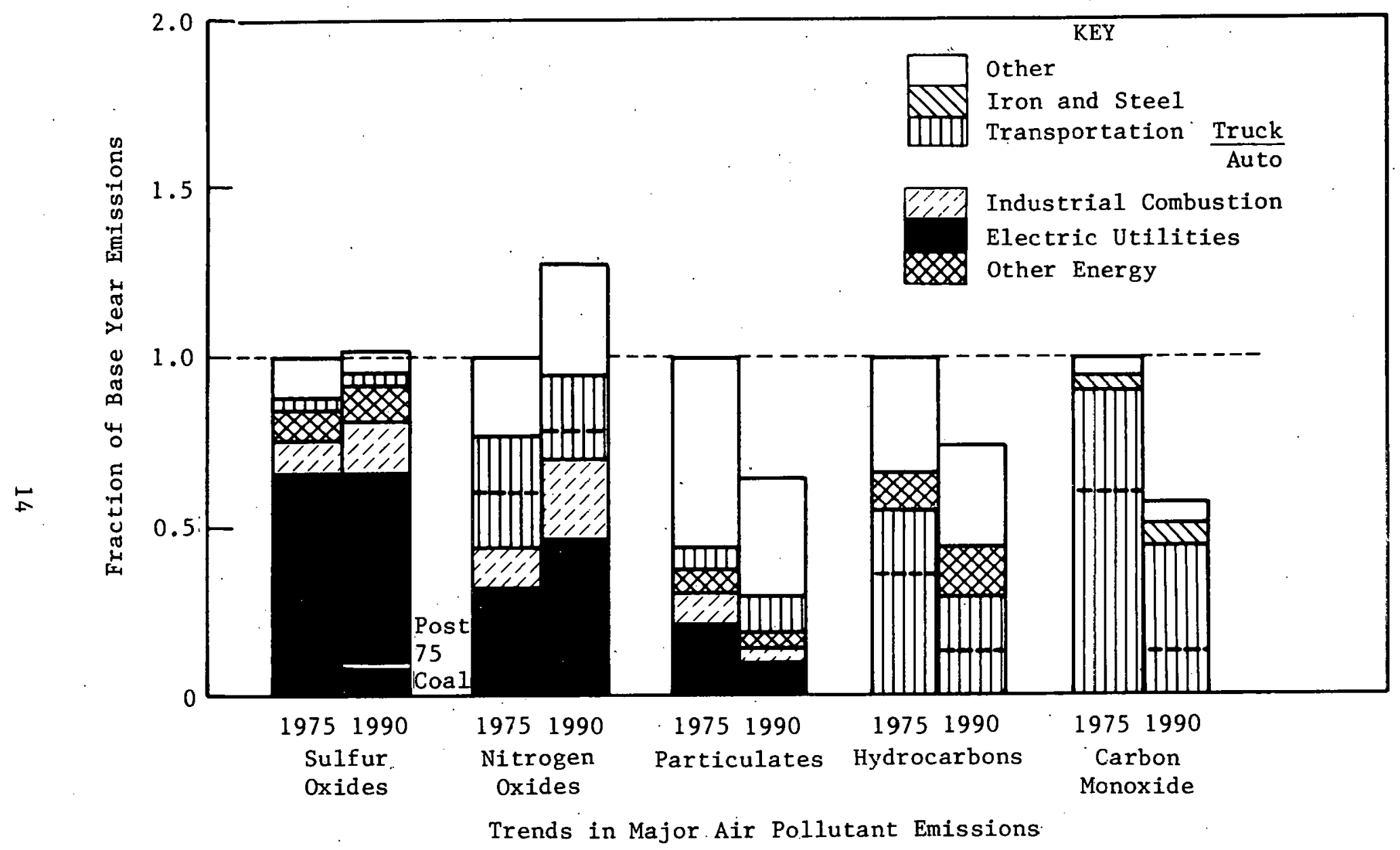

Source: National Environmental Impact Projection No. 1, 1978

FIGURE 2

EMISSION TRENDS FROM SEAS FOR NEIP NO. 1 


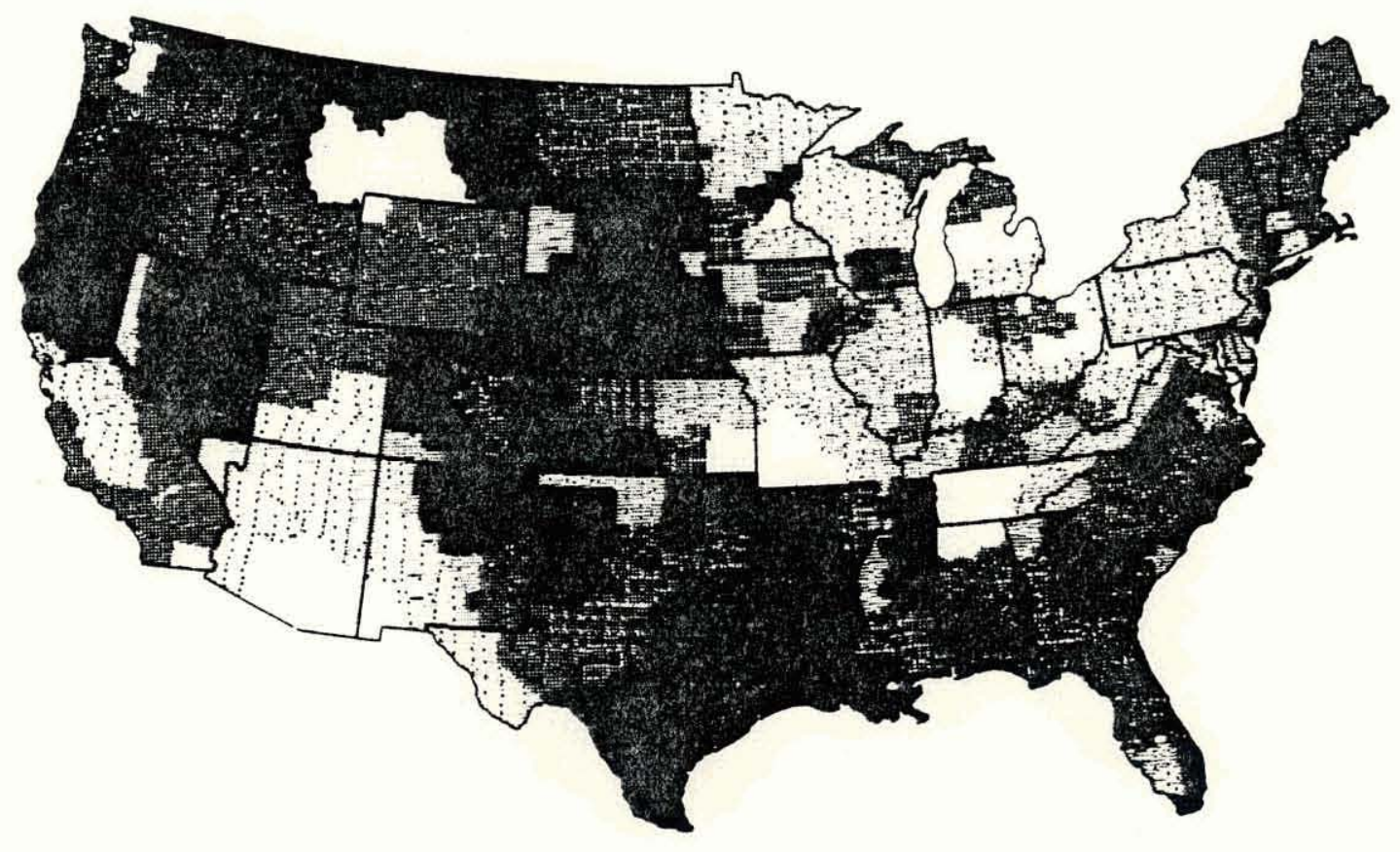

PERCENT OF BASE YEAR

Above $200 \square 125$ to 200 to 75 to $125 \square 0$ to

Projected Sulfur Oxide Emissions in 1990 by AQCR

Source: National Environmental Impact Projection No. 1, 1978

FIGURE 3

REGIONAL PROJECTIONS FROM SEAS FOR NEIP NO. 1 
economic growth. Two economic growth rates (high and low) were used to design two complete scenarios. The SEAS model was then run for each scenario to produce two environmental pictures through the year 2000 .

SEAS results were analyzed on a pollutant-by-pollutant basis for air, water and solid waste trends. This analysis provided pollution trends for the nation and each of the ten Federal Regions. The Environmental Outlook addresses the preliminary implications of these trends.

Individual briefings are prepared from the Environmental Outlook for the ten Regional Administrators and their senior staff. Figure 4 depicts a typical product of this analysis showing future problem areas in Region VI with regard to sulfur oxide and nitrogen oxide emissions.

ISSUE SPECIFIC ASSESSMENTS

Many assessments are best performed by focusing on specific issues. For example, in cases where decision makers must choose the "best policy" from among a number of competing options, SEAS can be used to predict the economic and environmental consequences of each alternative. By providing a consistent framework in which to compare the costs, benefits, and risks associated with each option, SEAS helps policy makers reduce the uncertainties under which decisions are made.

SEAS has been used in support of the following issue-specific studies : 

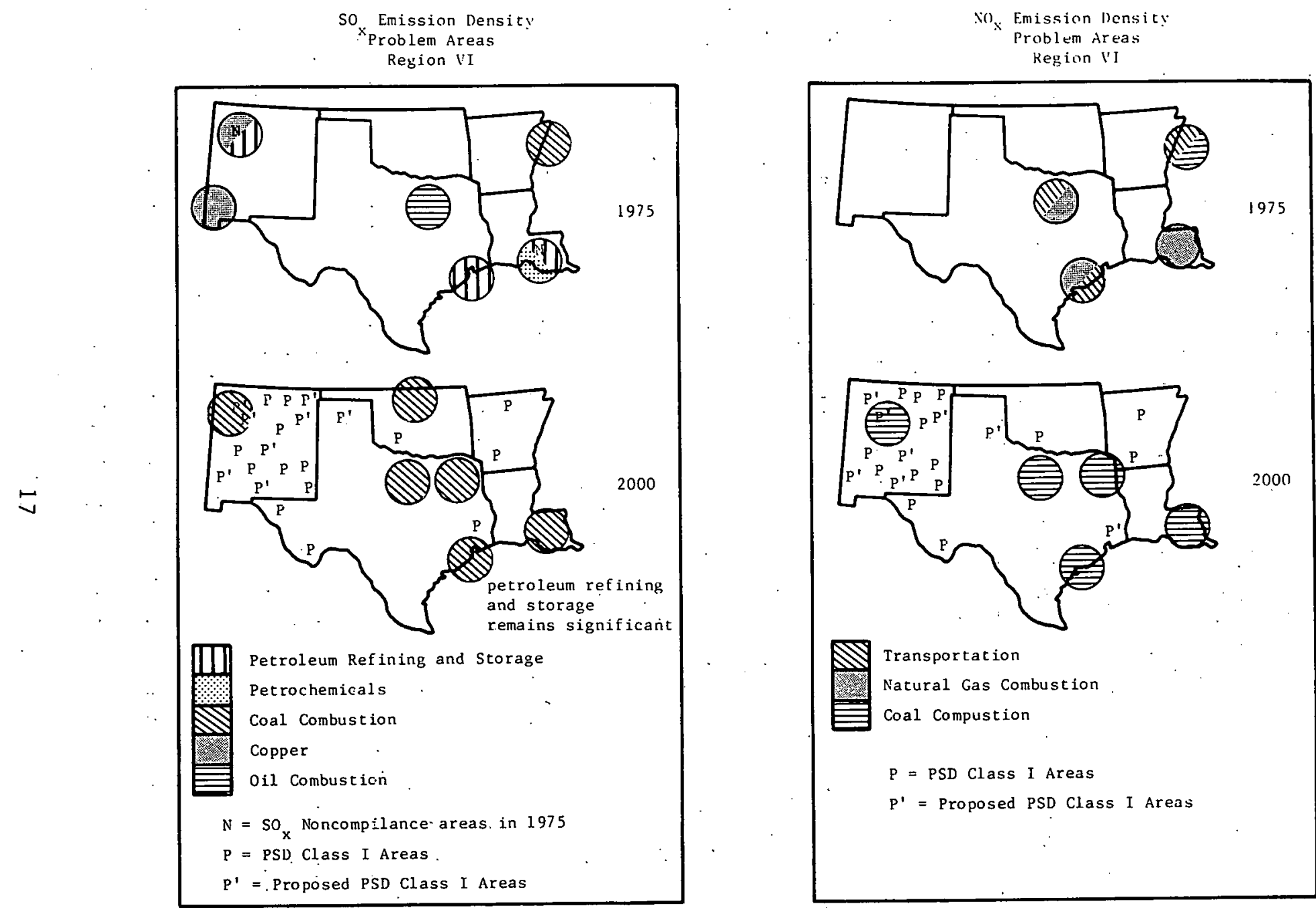

FIGURE 4

USE OF SEAS IN REGION VI BRIEFING 
- Analysis of Revised New Source Performance Standards

- Effects of Gasoline Rationing

- Health and Ecological Effects of Increased Coal Use

- Technology Assessment of Solar Energy

- Acid Rain Mitigation Study

A brief summary of the results of the first two of these studies are presented below.

\section{New Source Performance Standards}

DOE used SEAS to develop formal comments on EPA's proposed New Source Performance Standards (NSPS) for electric utilities and industrial boilers. Using the energy scenario contained in the National Energy Plan (NEP), the Department forecasted emission levels under the five different NSPS options. These options assumed various control efficiencies (as represented by the use of stack gas control devices) for those new electric utilities and industrial users expected to burn coal under the NEP.

Table IV shows the varying assumptions made for NSPS for sulfur oxides, total suspended particulates, and nitrogen oxides. Each of these policy options, which assumed a different level of control would be required by the NSPS, were modeled to give the projected emissions levels for each of the three pollutants. Table V suinmarizes the results for sulfur oxides. These results were also examined by (DOE) Federal Region to determine regional impacts. Impact projections such as these offered preliminary data to support decisions about the cost/risk/benefit tradeoffs of alternative control options. 
TABLE IV

NEW SOURCE PERFORMANCE STANDARDS (NSPS) OPTIONS

(Applies to Coal-Fired Units)

\begin{tabular}{|c|c|c|}
\hline OPTION & ELECTRIC UTILITIES & INDUS TR IAL BOILERS \\
\hline NSPS 1 & $\begin{array}{l}\text { Current NSPS: } \\
\mathrm{SO}_{\mathrm{x}}-1.21 \mathrm{bs} / \mathrm{million} \mathrm{Btu} \\
\text { Particulates }-0.2 \cdot 1 \mathrm{bs} / \\
\text { million Btu } \\
\mathrm{NO}_{\mathrm{x}}-0.7 \mathrm{lbs} / \mathrm{million} \mathrm{Btu}\end{array}$ & $\begin{array}{l}\text { Current NSPS - applies to } \\
\text { boilers greater than } 25 \\
\text { MW(e): } \\
\mathrm{SO}_{\mathrm{x}}-1.2 \text { lbs/million Btu } \\
\text { Particulates - } 0.1 \text { lbs/ } \\
\text { mllion Btu }\end{array}$ \\
\hline NSPS 2 & $\begin{array}{l}\text { Revised NSPS in } 1984: \\
\mathrm{SO}_{\mathbf{x}}-90 \% \text { removal at } 97.7 \% \\
\text { reliability. Maximum } \\
\text { emissions } 0.8 \text { lbs/million } \\
\text { Btu average } \\
\text { Particulates }-0.03 .1 \mathrm{bs} / \\
\text { million } \mathrm{Btu} \\
\mathrm{NO}_{\mathrm{x}}-0.6 \mathrm{lbs} / \mathrm{million} \mathrm{Btu}\end{array}$ & $\begin{array}{c}\text { Same as NSPS } 1 \\
\therefore\end{array}$ \\
\hline NSPS 3 & $\begin{array}{l}\text { Same as NSPS } 2 \text {, except } 80 \% \\
\text { sulfur removal }\end{array}$ & Same as NSPS 1 \\
\hline NSPS 4 & Same as NSPS 2 & $\begin{array}{l}\text { Revised NSPS in } 1981- \\
\text { applies to bollers greater } \\
\text { than } 25 \mathrm{MW}(\mathrm{e}): \\
\mathrm{SO}-90 \% \text { removal at } 90 \% \\
\text { reliabillty. Maximum } \\
\text { emissions } 0.8 \text { lbs/million } \\
\text { Btu average }\end{array}$ \\
\hline NSPS 5 & Same as NSPS 2 & $\begin{array}{l}\text { Large bollers - same as } \\
\text { NSPS } 4 \\
\text { Small boilers - } 70 \% \text { removal } \\
\text { at } 90 \% \text { reliability. Maxi- } \\
\text { mum emisstons } 1.2 \text { lbs/ } \\
\text { million Btu average }\end{array}$ \\
\hline
\end{tabular}

* The regulation was promulgated in 1979 but, because of construction time in building a utility, it is not effectlve unti1 1984. 
TABLE $V$

RESULTS OF NSPS STUDY

(Million Tons)

National Sulfur Oxide Emissions

\begin{tabular}{lllll}
\hline OPT ION & 1975 & 1985 & 1990 & 2000 \\
\hline NSPS 1 & 26.4 & 29.3 & 30.6 & 33.6 \\
NSPS 2 & 26.4 & 29.0 & 29.6 & 31.7 \\
NSPS 3 & 26.4 & 29.1 & 29.9 & 32.3 \\
NSPS 4 & 26.4 & 28.7 & 29.0 & 30.5 \\
NSPS 5 & 26.4 & 28.3 & 27.9 & 28.0 \\
\hline
\end{tabular}

Composition of Sulfur Oxide Emissions

\begin{tabular}{|c|c|c|c|c|c|c|}
\hline \multirow[b]{2}{*}{ OPTION } & \multicolumn{3}{|c|}{1985} & \multicolumn{3}{|c|}{2000} \\
\hline & UTILITIES & INDUSTRIAL & OTHER * & UTLITIES & INDUSTRIAL & OTHER \\
\hline NSPS 1 & 17.4 & 7.3 & 4.6 & 16.9 & 11.7 & 5.0 \\
\hline NSPS 2 & 17.1 & 7.3 & 4.6 & 15.0 & 11.7 & 5.0 \\
\hline NSPS 3 & 17.2 & 7.3 & 4.6 & 15.6 & 11.7 & 5.0 \\
\hline NSPS 4 & 17.1 & 7.0 & 4.6 & 15.0 & 10.5 & 5.0 \\
\hline NSPS 5 & 17.1 & 6.6 & 4.6 & 15.0 & 8.0 & 5.0 \\
\hline
\end{tabular}

*Primarily residential/commercial fuel use, petroleum refining, paper plants, and smelters. 
For issue-specific analysis, SEAS output can be limited to those areas relevant to the policy options being considered. In the foregoing analysis, for example, other parameters such as water pollution, water use, land use, and occupational health and safety issues were not addressed. However, because the question of scrubber sludge was of particular interest, projections for this solid waste were made for each NSPS option evaluated. Gasoline Rationing

The Economic Regulatory Administration (ERA) within DOE used SEAS to study the effects of gasoline rationing [Lawrence, 1978]. According to the National Environmental Policy Act (NEPA) any major federal action likely to impact the environment requires the preparation of an Environmental Impact Statement (EIS). Gasoline rationing was preceived as having a potential impact. The purpose of this analysis was to determine whether or not the proposed rationing plan would constitute a major federal action requiring a full EIS.

A baseline scenario was created for comparison purposes, which assumed the fuel allocation program used during the 1973-1974 oil embargo was in effect. Since the proposed rationing plan was designed to maximize equity, the gasoline rationing scenario assumed a given shortfall of supply would be equally spread among the states as a percentage of demand.

These assumptions were translated into different regional values of vehicle miles traveled by automobiles and light trucks, and 
entered into the SEAS Transportation Module. The result was different transportation-related air emissions by state. These changes were compared with the total state emissions. In this way the emission differences created by the gasoline rationing plan were measured. EPA determined from these results that the gasoline rationing program would not have a major impact on air pollution; thus an Environmental Impact Statement was not warranted. 


\section{HOW SEAS WORKS}

SEAS consists of several computer models or modules which integrate energy, economic and environmental forecasts within a consistent framework. SEAS can best be thought of as an accounting system for a large data base, with two distinct sides: energy and nonenergy. The energy side of SEAS is defined as those sectors which produce, process, transport, or directly combust some form of energy. Examples of such energy sectors would be the oil sectors which drill, refine, transport, and eventually burn petroleum: The sectors on the non-energy side of SEAS are those sectors where pollutants are dependent on the production of a specific product as opposed to the flow of energy. For instance, the pollutants or by-products resulting from the production of chemicals or pulp and paper. An important concept to remember is that an industry (such as iron and steel) will have emissions associated with both energy and non-energy activities.

SEAS accepts various energy and economic assumptions, for example, the Gross National Product (GNP) and the end-use energy consumption by fuel type for specified years (e.g., 1985, 1990, and 2000). SEAS then computes energy activity (in Btus) for the energy sectors and economic activity (in dollars or tons) for the non-energy sectors consistent with the given scenario forecasts.

Residual coefficients are used to convert the energy and economic activities into tons of pollutants. For example, tons of 
particulates emitted by old (pre-1975) coal-fired utility plants are computed by multiplying the residual coefficient for particulates from old coal-fired utility plants by the activity level for that sector. Associated with many coefficients is a removal efficiency reflecting the use of pollution control equipment. In this way, SEAS computes both gross (total emissions) and net (emissions after applying controls) pollution discharges. Residual coefficients can change regionally and over time. For example, many coefflcients for sectors which burn coal are entered by state to reflect different percentages of sulfur and ash of the coal burned in each state.

Regionalization of the energy and non-energy activity levels is done by several methods. Detailed data bases on existing and planned activity are used to site the major energy sectors - such as electric utilities, industrial combustion and coal mining. Regionalization of non-energy sectors is based on projections of economic activity by the Office of Business and Economic Research (OBERS). For many sectors which contribute large amounts of pollution, such as copper smelters or steel mills, specific data on where these facilities are currently located and are expected to be located is contained in the model.

Regionalization is initially done at the county level since counties are the common elements of all SEAS regions. However county siting information is not reported by SEAS. The county level activities are aggregated up to the SEAS reporting regions, such as Federal 
Region, State, or Air Quality Control Region. Regional pollution estimates are derived by taking the regional activity level times the regional emissions coefficient. Pollution estimates can also be calculated at the national level and then regionalized.

The basic SEAS model consists of the eleven major modules* shown in Figure 5. These modules are organized into four functional categories: Energy, Economic, Regional and Environmental. The eleven modules are discussed briefly below. Additional detail can be found in other volumes of this report described in the foreword. ENERGY MODULES

The energy category contains four energy-related modules:

- Electric Utilities (EUM),

- Industrial Fuel Use (IFUM),

- Coal Mining (CMM), and

- the Energy System Network Simulator (ESNS).

The energy modules are concerned with determining detailed national energy flows and regionally siting industrial fuel use, coal mining and electric utility activity. The ESNS module works at the national level determining intermediate energy flows and primary energy supplies consistent with a given set of end-use energy

\footnotetext{
* There are other modules in the SEAS system which are not discussed here. Examples are (1) PRESEAS which is a set of interactive programs that format data from two DOE National Energy Models (MEFS and FOSSIL2) so that it is acceptable to SEAS; (2) AIRTRANS which computes the long-range transport of certain air emissions; and (3) PERQUAD, which computes the direct and indirect effects of individual energy technologies.
} 


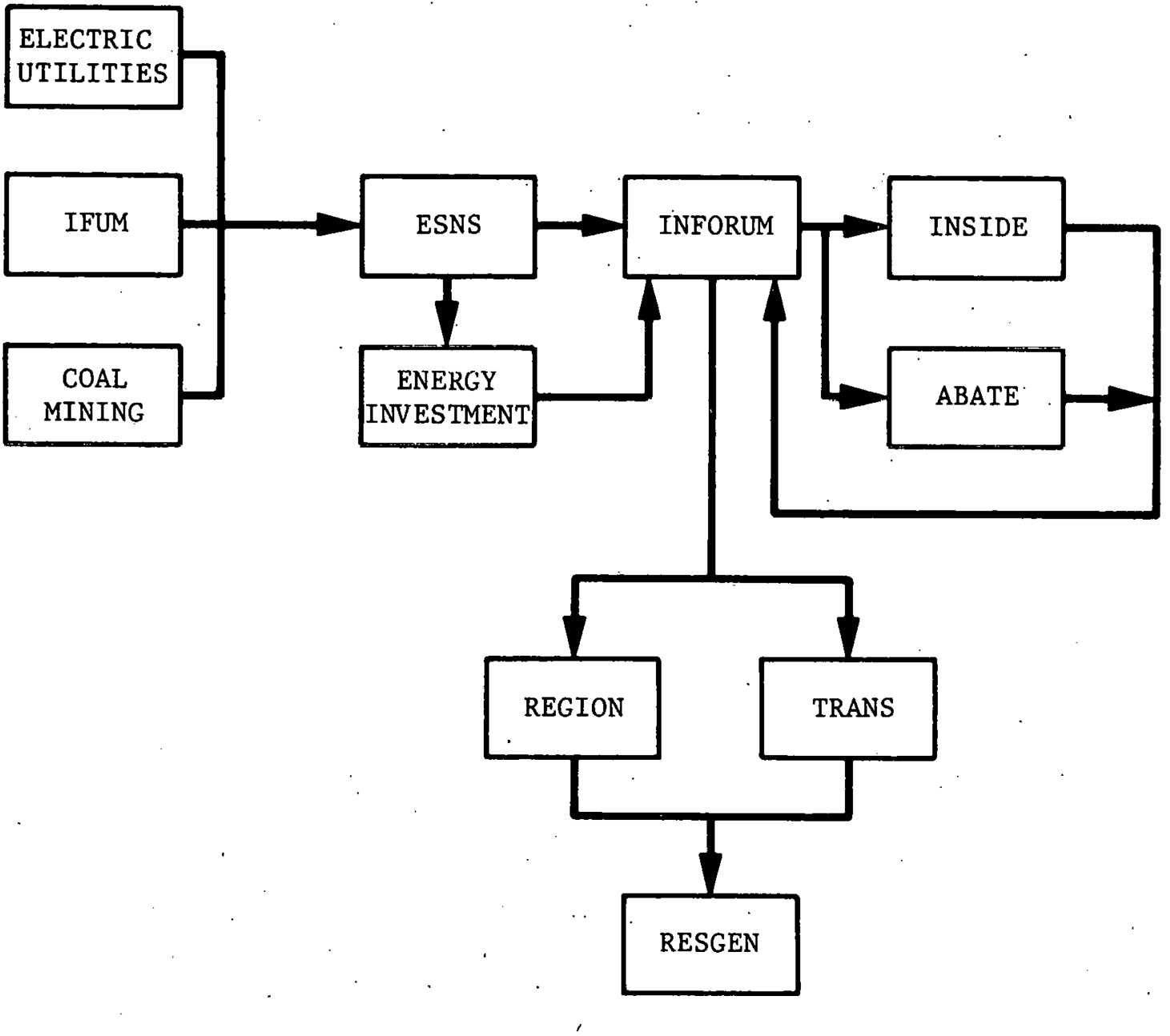

FIGURE 5

THE BASIC SEAS MODULES 
consumption forecasts derived outside of SEAS. The energy forecasts are disaggregated by ESNS because pollution and environmental regulations are associated with specific energy technologies and processes. Because of the important environmental impacts from industrial boilers, coal mines and electric utilities, special modules were created for siting the activities associated with these energy sectors. The three siting modules calculate information at the county level. Electric Utilities

The primary purpose of the Electric Utilities Module (EUM) is to regionalize capacity of conventional (i.e., coal, oil, gas and nuclear) electric utility plants in a manner that is consistent with a pre-specified scenario. The energy demands are supplied by either the FoSsIL2 National Energy Mode1 or the Mid-Term Energy Forecasting System (MEFS). When the FOSSIL2 model is used, the inputs to the EUM are at the national level; when MEFS supplies the inputs, they are at the federal region level.

The Electric Utilities Module has several functions. According to the specifications of a scenario, it allocates generation capacity to specific counties, for both existing and new conventionally fueled electric utility plants.* These allocations are input to the regional disaggregation module (REGION) in the form of county share

\footnotetext{
*Existing plants are defined as those in operation prior to 1 January 1976; new plants are defined as those coming on line after 1 January 1976.
} 
files for new and existing conventional electric utilities. The county shares are applied to national values to regionalize the energy activity or the pollution (other than particulates and sulfur oxides) generated by the electric utilities.

The EUM calculates particulates and sulfur oxides emissions from existing coal and oil-fired utilities. These calculations incorporate State Implementation Plan (SIP) emission standards and New Source Performance Standards (NSPS) where applicable. This information is input to the residuals generation module (RESGEN) for inclusion in the residuals output reports.

A final function of the EUM is to provide inputs to ESNS. By supplying files containing data on total electricity generation, the EUR1 permits ESNS to pattern the distribution of energy in electricity generation.

There are three major steps in the EUM. The first step is to forecast existing plant generation and pollution emissions. The next step is to calculate the amount of new capacity necessary to fulfill the requirements of the scenario. The final procedure is to allocate the new generation to suitable counties, while meeting the scenario requirements. These steps are more fully discussed in the following paragraphs.

The major inputs to the EUI include the national or regional demand for the four conventional fuels (coal, oil, natural gas, and 
nuclear) and the renewable energy sources.* other inputs to the EUM include:

- The Federal Energy Regulatory Commissions's (FERC) file of existing conventional utility plants.

- An announced plant list provided by Oak Ridge National Laboratory containing those plants scheduled for construction through 1990, as reported by the utility companies.

- A compilation of all plants mandated to convert to coal in accordance with the ESECA, provided by Oak Ridge National Laboratory.

- A rank-ordered list of potential future sites for conventional utility plants, provided by Teknekron Research, Inc.

- A list of scheduled existing powerplant boiler retirements by year, provided by Oak Ridge National Laboratory.

As stated earlier, the first step in the EUM is to forecast existing plant generation and pollution emissions. Projections of existing utility plant generation (in MWHs) by fuel type (coal, oil, gas and nuclear) are calculated accounting for unit retirements, ESECA conversions, and any other fuel-switching. It is assumed that these plants will be regulated by State Implementation Plans (SIPs), unless fuel-switching occurs.** Under the Energy Supply

\footnotetext{
${ }^{\star}$ Renewable energy sources include hydroelectric, geothermal, solar thermal, photovoltaics, wind and biomass. These are'further broken down into subcategories in ESNS.

**Environmental regulations for switches under ESECA are less stringent (controlled under SIPs) than switches occurring at the discretion of the plant owner (controlled under NSPS). The law states that modifications to plants which increase the plant emissions are to be controlled by the NSPS standard. If the plant was designed to switch fuels, then it would not be controlled under NSPS.
} 
and Environmental Coordination Act of 1974 (ESECA), certain electric utility plants are required to switch from oil and gas to coal by 1985. Emissions from these converted plants are calculated using the unit-specific SIPs.*

For all existing plants using conventional fuels, future generation is calculated at the unit level. Each fuel type is summed for each target year to the county level (taking. into account those units that switched fuels). Then, total MWHs retired, by fuel and county, are subtracted giving generation'for existing plants at the county level. Emissions of particulates and sulfur oxides are calculated in a similar manner taking into account the applicable pollution standards. After the calculation of future year generation and pollution for existing electric utilities, plant output is calibrated at the county level to match the scenario-specific demand for electricity from old plants.

The next step in the EUM is the determination of state demand for new electric generation. To calculate state demand for new conventional electricity generation, two data sets are necessary:

- Calibrated existing plant generation for all forecast years.

- Renewable energy sources by type, location, and generation by target year.

The total national or federal region demand for electricity, as specified by the scenario is disaggregated to the state level

\footnotetext{
* The SIPs were supplied by James Carroll, U.S. EPA, Office of Policy Analys is, September 1980.
} 
for each target year, based on projections derived from the National Electricity Reliability Council's (NERC) forecasts and the office of Business and Economic Research (OBERS) forecast of population. State demand for new conventional electricity generation is then calculated by subtracting existing.plant generation and generation provided by renewable energy sources from the total state demand.

The final step in the EUM is to site this new generation in spectfic counties. The announced plant list is used initially to site plants by state. The information contained on the list includes location (state and county), capacity in MW, fuel type, and planned opening date of each plant. The planned opening date is used as an ordering mechanism to ensure that plants are opened in the sequence specified by the utility industry.

The announced plant list does not always contain enough plants to meet the entire projected demand by the final target year. To meet the additional demand, a county rank-weighted list, prepared by Teknekron Research, Inc., is used. The result of this siting procedure is a set of new plant (post-1975) net generation values, by county, for each of the coal, o11, gas and nuclear fuels in 1985 , 1990 and the final target year.

Industrial Fuel Use Module

The Industrial Fuel Use Module (IFUM) computes future Industrial fuel use in sufficient detall to estimate likely future pollutant emissions. This is accomplished by disaggregating fuel use in two 
different ways. The model disaggregates the projected level of industrial fuel use into nine categories. Each of these categories represents a certain type of fuel (i.e., coal, gas, or ofl) combusted under one of the three standards. The model also regionalizes fuel use to the county level in order to incorporate standards which vary geographically. This is especially important for old or existing (pre-1976) industries which are controlled under State Implementation Plans (SIP's) that vary within a state, sometimes from county to county.

Although IFUM produces results at the county level, these results are only used internally within SEAS. SEAS aggregates the county values back up to substate regions (e.g., Air Quality Contro1 Regions and Bureau of Economic Analysis Regions), States, Federal Regions, and the entire nation. IFUM is not intended to be used as a county-level forecasting module.

Because of the variety of pollution emission standards that may apply to industrial boilers, IFUM must differentiate industrial fuel combustion based on the age, size, and location of the boilers, and the type of fuel that is burned. For example, new industrial plants coming on line after some future year are usually under stricter standards than existing plants operating under the original State Implementation Plans (SIP's). IFUM also models industrial fuel use subject to standards which differ geographically; such as State Implementation Plans that vary from county to county within a state. 
Three types of emission standards are assumed by IFUM. State Implementation Plans, which affect existing bollers or small bollers built before a designated future year, can vary within a state depending on the air quality in an area. New Source Performance Standards (NSPS's) apply to new bollers built before a designated future year and which have a capacity greater than 250 million Btu's per hour heat input. Revised New Source Performance Standards affect new industrial boilers bullt after a designated year. Revised NSPS's were not promulgated by March 1980 , but best estimates of the standards are included in IFUM.

The scenario dependent input to IFUM is the projected level of fuel consumption at the National and/or Federal region level. These projections come from MEFS or other exogenous sources. Other data required by IFUM include:

- Base-year federal region and state fuel use,

- Expected conversions from existing gas and ofl to coal under ESECA,

- The base-year and projected level of industrial activity by state as forecast by OBERS,

- Data on size, age and location of existing large facilities from the Major Fuel Burning Installation (MFBI) tape.

Coal Mining Module

The Coal Mining Module forecasts the location by county of underground and strip mine coal extraction. Scenario dependent inputs to the module are projections of coal requirement by supply method - underground or strip. This data usually comes from MEFS. 
Additional information is needed on the production from existing mines, planned. mine openings and county coal reserves. The module operates with the assumption that existing and planned mines will supply the near-term coal needs. Additional demand for coal is determined by the user specifying a future distribution for 12 coal supply regions. Information on coal reserves is then used to distribute this activity to counties. As with the utility module and IFUM, this county information is aggregated to the SEAS regions (e.g., Air Quality Control Region, States, etc.) before reporting. The Energy System Network Simulator (ESNS)

The ESNS module simulates a network of primary energy supply activity, intermediate energy sectors and end-use energy demands. Primary energy supply activities are defined as extraction or imports and include energy activities such as coal mining (underground and strip), oil shale extraction, uranium mining, and crude oil imports. ESNS contains approximately 40 primary supply activities.

Intermediate energy sectors are those necessary for completion of the production cycle and include conversion, processing, refining, and distribution. Coal transport to utilities, utility generation of electricity from coal and the distribution of electricity to consumers all represent intermediate activities. SEAS contains approximately 150 intermediate activities.

End-use demand activities are defined as activities which involve the consumption of energy or the use of energy as a feedstock. 
Industrial combustion of coal is an end-use demand activity. There are currently 32 of these demand sectors in SEAS. Each supply, intermediate and demand activity becomes a SEAS sector which subsequently is regionalized and has pollution coefficients associated with it.

The energy flow through the ESNS network is uniquely defined by specifying the Btu's consumed by each of the demand activities, the efficiencies associated with intermediate energy sectors, and the allocations of energy delivered between competing technologies. Allocations are defined as the percent of energy supplied by a given technology or activity at a given node on the network. For example, electricity can be generated by coal, oil, gas, photovoltaics, biomass, nuclear, hydroelectric, wind and geothermal energy. Allocations specify at any given time how much electricity is being gener- : aled by each of these technologies. The efficiency of a process is ? defined as the ratio of energy produced to the energy entering the process. For example, oil refining has a 92 percent efficiency which means that 92 percent of the Btu's in the crude petroleum entering the refinery are contained in the final petroleum products..

SEAS operates in a mode that calibrates to the scenario specific inputs derived from other energy models. This means that the demands, efficiencies and allocations are adjusted, when necessary, to represent the outputs of other models. This, ESNS is used to 
disaggregate energy forecasts from other models, so that SEAS has detailed energy information to estimate probable levels of pollution. ECONOMIC MODULES

The economic modules represent the flow of materials and services for all sectors of the economy. There are four economic modules: Interindustry Input/Output (INFORUM), Sector Disaggregation (INSIDE), Energy Investment (INVEST), and Pollution Abatement (ABATE). These modules are related among themselves and to the energy modules as shown in Figure 6. The national level energy projections are input to the economic modules from ESNS. Additional assumptions on general economic growth and employment are entered directly into INFORUM.

The INFORUM Module

The INFORUM module provides projections of the non-energy activity levels consistent with the energy activity levels projected in the energy modules. INFORUM encompasses both a detailed inputoutput model as well as a comprehensive set of econometric projections for the components of Gross National Product (GNP) through the year 2000. The input-output part consists of a 200-sector model that represents and projects the interrelationships between each of these sectors of the economy [Almon, 1974] . These buyer-seller relationships are represented in the form of input-output coefficients which indicate for any sector (buyer) how much it needs as input from each of the other sectors (sellers) per dollar of output that it produces. 


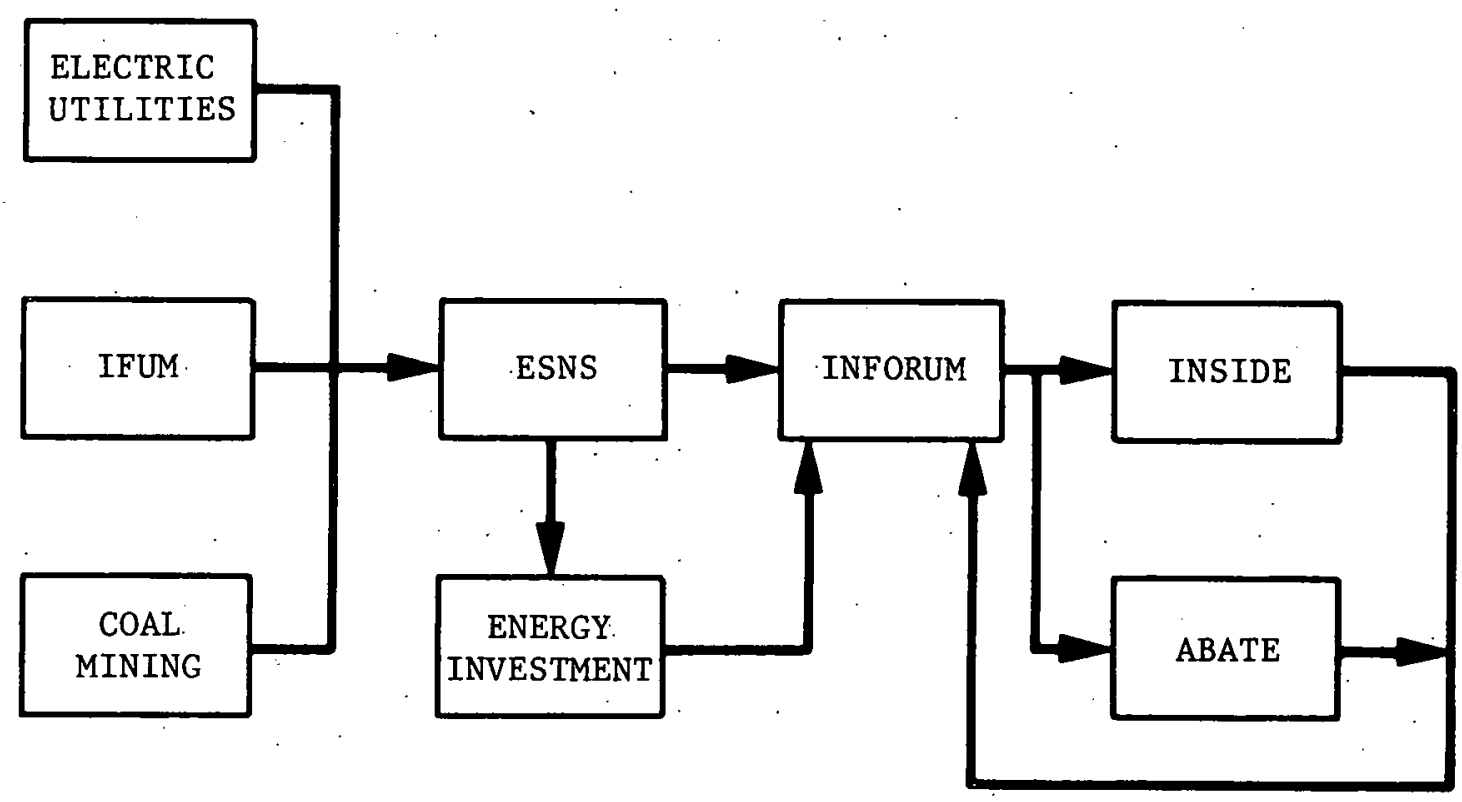

FIGURE 6

THE ENERGY AND ECONOMIC MODULES 
These input-output coefficients are estimated for the base year (1975) and are also projected to 2000. The projections are based on historical trends, changes in relative prices of each input, and other factors such as pollution abatement requirements.

A complete depiction of the flows through an economic system must recognize that each sector also sells its product to final demand. This is in addition to selling its product to other sectors for intermediate use (i.e., as an input to its production process). It is in the final demand projections that the key econometric features of the model are embodied. Final demand represents the main components of the Gross National Product. Forecasting equations are incorporated for each of the major components of final demand:

- Consumption equations for each of about 150 products;

- Investment equations for each of 90 sectors that purchases producer's durable equipment (e.g., the automobile sector);

- Construction equations for each of 30 sectors that build, plants and homes;

- Export and import equations for each of the sectors that enters into trade between the U.S. and the rest of the world; and

- Equations for certain categories of Government expenditures (e.g., State and local expenditures on schools, highways, etc.).

The remaining components of final demand (such as defense expenditures) are provided exogenously by the users. The link between these final demand components and the 200-sector input-output model is made through a series of final demand matrices (similar to the 
input-output coefficient matrix). These matrices allocate a dollar of final demand purchase (e.g., residential construction) to each of the 200 sectors of the model (steel, cement, plywood, etc.).

The distinction between intermediate and end-use products can be illustrated using an example. Steel as an intermediate product may be bought by the motor vehicle industry to manufacture an automobile (which in turn is sold to household consumers). Alternatively, the steel may be purchased directly by an end-use buyer to build an electric. power plant (types of structures). The total output of any industry is the sum of the products sold as intermediate sales and as final demand sales.

The key advantage of INFORUM is that it is a consistent whole. An industry's investment is consistent with its production of output. The output of an industry is consistent with the total demand of its products by all purchasers, consumers, government, or other industry. The employment of an industry is consistent with its output and productivity. Consumers' demand for a product is consistent with trends in demand for a particular product and consumer income.

In SEAS, INFORUM is run in an iterative fashion to target on the GNP and energy forecast of the given scenario. Final demand requirements for energy investment and pollution abatement are estimated within separate modules (INVEST and ABATE) that feed back those requirements to the input-output model. These and other final demands create a level of disposable income, which in turn determines all 
household and state and local govermment purchases by sector. If these feedbacks result in aggregate expenditures that are greater (or 1ess) than the targeted GNP, disposable income is lowered (or raised) and the model reruns until equality with this target is achieved. Since SEAS is an input-output model it tracks both direct (for example, steel for making solar collectors) and indirect (for example, coal for making the steel in solar collectors) impacts. The final set of estimated outputs is a consistent reflection of the GNP, energy targets and the resource requirements (direct and indirect) implied by the scenario.

Sector Disaggregation (INSIDE)

The purpose of the INSIDE Module is to disaggregate the INFORUM sector forecasts into greater detail. This detailed breakdown allows for more accurate calculation of pollution generation and abatement cost. The following example serves to illustrate this point:

- the INFORUM model depicts the major part of the chemicals industry as a single sector -- Industrial organic and inorganic chemicals. INSIDE disaggregates this into key products such as chlorine, nitric acid, and acrylonitrile.

- One of the 200 sectors of the input-output model is the steel sector. In the INSIDE model this sector is disaggregated into processes at two levels. First, processes such as blast furnaces, sintering, iron foundries, steel production and feroalloy production are distinguished. Next, alternative processes for producing steel -- open hearth, electric arc and basic oxygen -- are represented.

- Nonferrous metals such as copper, lead, zinc and aluminum are each represented by a single sector in INFORUM. INSIDE disaggregates these into a 'primary' and a 'secondary' component since they have distinct pollution characteristics. Where necessary these are further characterized by alternative processes. 
This detail is needed because of differences in gross discharges of pollutant per unit of product and because EPA has legislated different standards for different processes. The projections of this module are performed through a series of linear equations that represent seller-buyer relationships similar to those in the input-output table. For example, the sales of chlorine are a function of the output of the sectors that use chlorine (e.g., pulp mills, water utilities) as well as final demand sales. The key factor is that these relationships can be different for chlorine than they are for the chemicals sector. Another important feature of INSIDE is that technological forecasts allow the shares of alternative processes to change over time; these projections are also subject to user overrides.

In all about 300 product/process sectors are represented in the INSIDE module. The projections of these sectors (which are typically in a unit such as tons rather than dollars as in INFORUM) enter into the residual and pollution abatement calculations. The Energy Investment Module (INVEST)

This module estimates capital requirements for construction of energy facilities. The results of these calculations enter into the final demand in the INFORUM model, which in turn determines the output of each of the 200 sectors of the economy. The Energy Investment Module provides technology detail not available in INFORUM. INFORUM contains only five energy sectors: coal mining, oil/gas exploration, 
petroleum refining, electric utilities and gas utilities. These five sectors are disaggregated in the ESNS Module to over 190 energy sectors. The energy sectors or technologies represent various parts of the energy cycle (supply, transportation, conversion and end-use). While the primary purpose of this detail is the characterization of the residuals from each step in the production and use of energy, it is also relevant for computation of capital expenditures for the construction of energy facilities.

INVEST begins with the energy supply and demand assumptions from ESNS. It then applies unit capital costs, construction time, and materials requirements to compute capital expenditures in each year of the investment period. There are two principal factors here. First, unit costs differ by technology (e.g., solar themal vs. conventional coal) and this data is represented in the model. Second, the materials requirements (on products such as steel, glass, cement, etc.) per dollar of investment also differ. This is relevant in the computation of indirect impacts and the projection of residuals from these sectors.

These energy investment expenditures are input to INFORUM as part of the final demand. In this way the INFORUM projections for energy investment are made to be consistent with the energy scenario specified in ESNS. 


\section{Pollution Abatement (ABATE)}

Like the Energy Investment Module, ABATE deals with capital requirements; in this module the requirements refer to facilities for air and water pollution abatement. In addition, it estimates the operating costs (e.g., materials, energy, labor) of pollution abatement faclities. For each sector requiring pollution abatement, the following input data is input to the model:

- the number of plants and their size distribution;

- equipment $11 \mathrm{fe}$ and construction time;

- compliance schedule; and

- unit capital and operating cost functions for pollution control equipment.

ABATE processes this information and reports capital and operating expenditures by.sector and by media (e.g., air, water, solid waste). As in the Energy Investment Module, the capital requirements are allocated to INFORUM sectors such as cement, pumps, and steel and are included in the final demand estimates prior to model solution. And the operating cost (or current account requirements) enters appropriate parts of the model as we11. The purchases of materials and energy impact on the input-output coefficients and the labor requirements are included in the employment calculations for each sector. Both the capital and operating costs affect the solution of the Input-Output model and are thus reflected in the residuals projections. 


\section{REGIONALIZATION MODULE}

There is one SEAS regionalization module, called REGION. It is used to convert national level forecasts into regional level forecasts, e.g., Federal Regions, States, Air Quality Control Regions, Aggregated Sub-areas (major and minor river basins), and Standard Metropolitan Statistical Areas.

REGION receives forecasts of activity for non-energy sectors from the INFORUM and INSIDE modules and forecasts for the energy sectors from ESNS. In addition, the Electric Utilities Module, the Industrial Fuel Use Module and the Coal Mining Module supply county shares information. Figure 7 illustrates how REGION relates to the energy and economic modules.

SEAS determines, for both energy and non-energy activities, whether the pollution associated with those activities is regionally dependent or not. For example, if the activity is the combustion of coal, the sulfur level in the coal will be important in determining the amount of $\mathrm{SO}_{2}$ emitted per Btu of coal burned. In this case, SEAS subdivides national coal burning activity into regions and then: applies a regionally-specific pollution coefficient to give $\mathrm{SO}_{2}$ emissions in the region.

For some activities, the amount of pollution per unit of activity does not vary. For example, if an industry is producing chlorine by the mercury cell process, the amount of pollution per ton of chlorine produced is the same regardless of where the industry is 


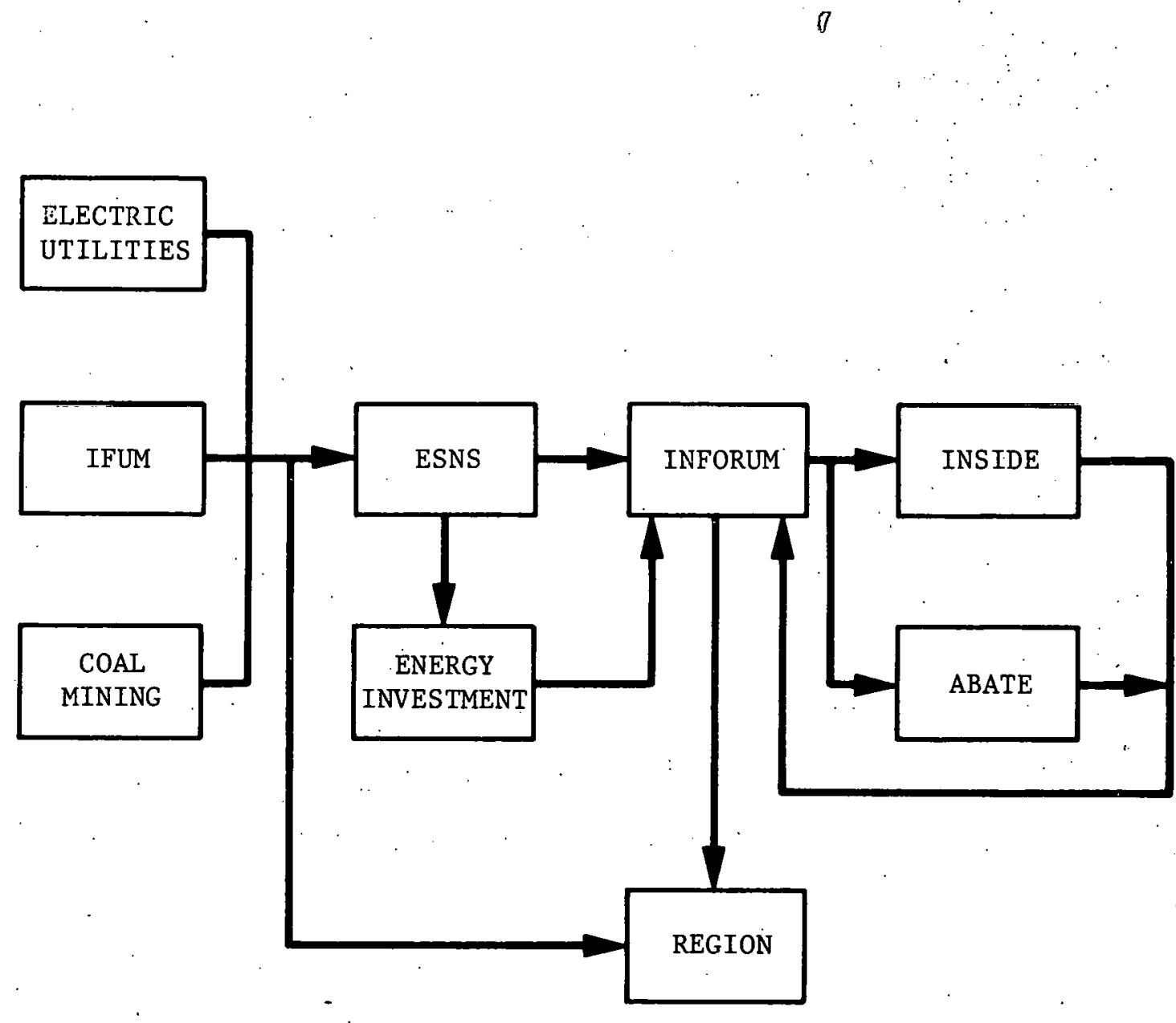

FIGURE 7

THE RELATIONSHIP OF REGION TO THE ENERGY AND ECONOMIC MODULES 
located. In this case, SEAS takes the national activity of the sector, and multiplies that by a national residual coefficient to get national pollution output. Then SEAS regionalizes the calculated pollution.

There are three different methods of regionalization performed by the REGION Module. This is in addition to the regionalization done by the Electric Utilities, Industrial Fuel Use and Coal Mining Modules.

Permanent Share Method

This method is scenario independent. An actual inventory of plant locations in the base year is combined with OBERS* regional forecasts for economic activity at the 2-digit SIC level to produce regional shares.** The OBERS forecasts are primarily based on trend extensions of regional activity compared with national activity. This is the most commonly used method for regionalization. Manual Override Share Method

Specific future shares are entered exogenously into the model for selected industries in which significant national shifts are anticipated, or for which environmental factors are especially significant. These shares have been developed in detailed industrial studies of the specific industries of concern. In addition, these

\footnotetext{
*OBERS (Office of Business and Economic Research) forecasts are prepared by the U.S. Department of Commerce and the U.S. Department of Agriculture.

**A share is defined as the fraction of national activity for a sector located in a region. The regional shares are normalized so that they sum to one.
} 
shares may vary from one scenario to another. Examples of sectors regionalized using the manual override procedure include petroleum refining and pulp and paper.

Dynamic Share Method

For certain sectors there are reasonably good data about the location and capacity of future plants. The dynamic share file is created on a scenario-dependent basis by proceeding down a list of anticipated plant sites until the demand is met. Shares are then calculated based on those plants required to meet the demand. This method is used for almost all.the energy sectors in SEAS except those sited in the energy modules. In particular, it is used for siting liquefaction, gasification, and oil shale facilities. ENVIRONMENTAL MODULES

The final category of SEAS modules calculates the environmental residuals for each region and sector. The two environmental modules are

- Transportation (TRANS), and

- Residual Generation (RESGEN).

The complete SEAS flow diagram is repeated in Figure 8. Transportation (TRANS) *

The Transportation Module calculates pollution from the transportation sector based on miles traveled and model year pollution

\footnotetext{
*A design has been developed to incorporate an improved version of the TECNET mode1 into SEAS. See Design Paper - Enhancement of the TECNET Model for Forecasting Transportation Activity, Energy Consumption, and Emissions, CONSAD Research and The MITRE Corporation, Draft, April 1980.
} 


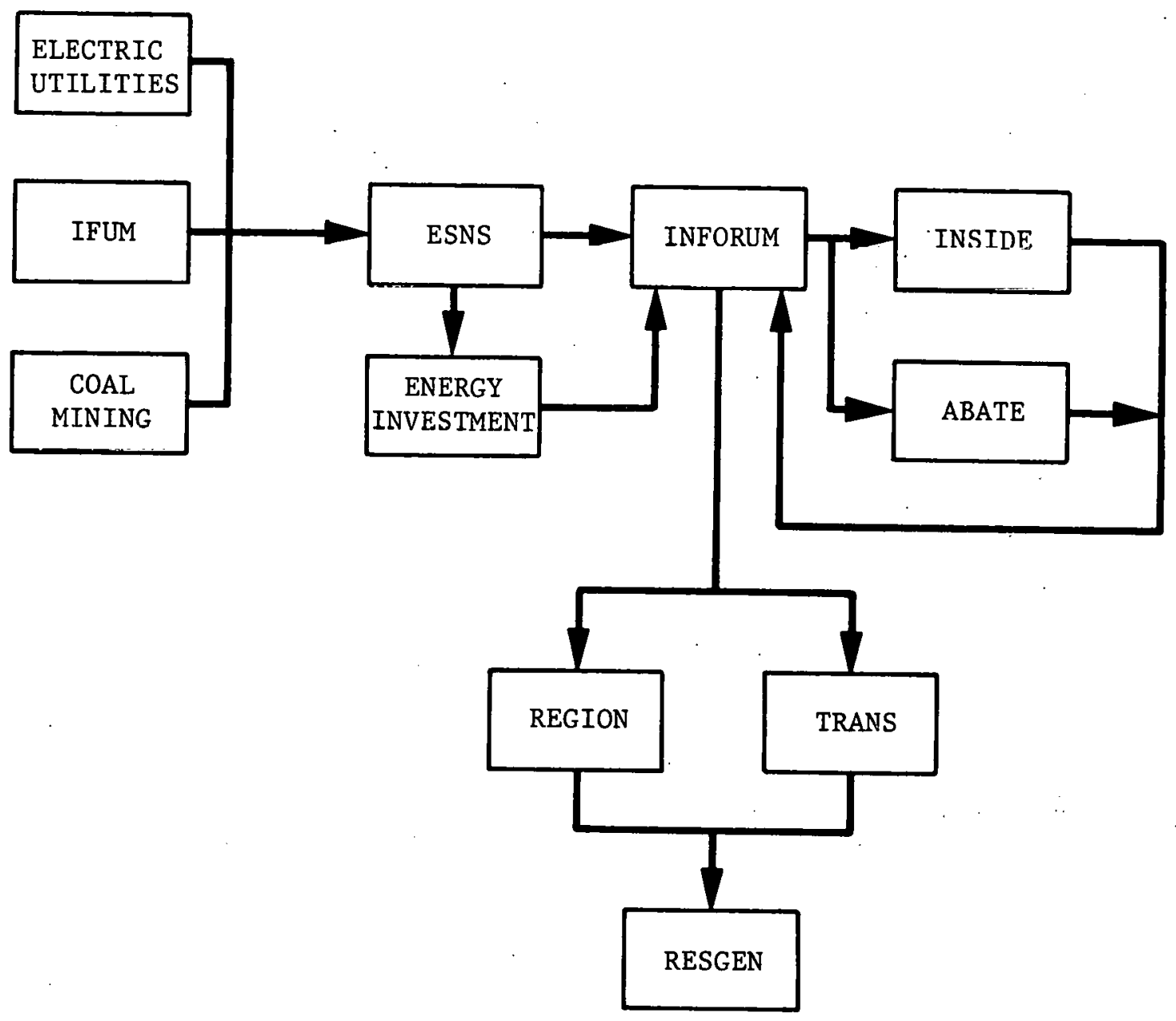

FIGURE 8

SEAS FLOW DIAGRAM 
standaràs. TRANS forecasts of activity for each mode of transportation (e.g., auto, truck, rail, air) are based on GNP and the output of the transportation sector obtained from INFORUM. Additional inputs are emission standards, occupancy ratio, mode of transportation shares and the expected life of automobiles. The transportation emissions are sent to RESGEN for inclusion in the output reports. Residual Generation Module (RESGEN)

The Residual Generation (RESGEN) Module calculates the amount of environmental pollution generated, both regionally and throughout the nation, by major energy and non-energy sectors in the economy. It also calculates resources utilized (land and water use) and occupational safety measures (number of person-days lost, number of deaths and number of injuries).

Residuals are computed in two ways depending on the availability of data for different sectors. Regional pollution data is available for some sectors, while for other sectors only national pollution data is available. The two methods are:

1. RESGEN receives inputs of national activity levels from the INFORUM, INSIDE and ESNS Modules and calculates national residual outputs. This national residual output may be reported directly or fed into the REGION Module where it is disaggregated into regional outputs.

2. RESGEN receives inputs of regional economic activity levels from the REGION Module and calculates regional residuals which are reported directly or added up to the national level. 
These two methods create separate files which are merged to give a complete accounting of either national or regional pollution from both energy and non-energy sectors.

The RESGEN Module performs three basic computations: gross residuals, net residuals, and secondary residuals. Gross residuals refer to the amounts of pollution which would be emitted if no po1lution abatement was provided. For example, the amount of sulfur oxides which would be emitted from burning coal in an electric utiity plant without the use of scrubbers would be considered gross emissions of sulfur oxides. Net residuals are pollutant effluents from processes which have pollution abatement. The treatment of primary effluents usually results in the capture of some of those pollutants. Further treatment of the captured residuals results in the generation of secondary residuals (e.g•, scrubber sludge). 
THE SEAS DATA BASE

SEAS modules use an extensive data base containing detailed environmental, energy-related, and economic information. Every effort is made to maintain current data through frequent updating and validation. The many types of information are developed in a consistent manner, with much of the information keyed to specific industrial activities.

The more than 200 data files that compromise the SEAS data base are derived from information from numerous government reports, documents by and communication with university personnel, government laboratories and contractors, and various industry trade associations. Government reports cited include, to indicate only a few, Federal Power Commission data on powerplant locations and capacities, DOE studies of energy technology costs and emissions and effluents, EPA effluent limitations guidelines development documents, and Bureau of the Census and other Department of Commerce publications and data. bases.

The following sections describe the types of information within some of these data files. A concluding section identifies some of the primary data sources and provides a brief evaluation of the quality and currency of various data within the system. Additional information on current status of the data base can be found in [McBrien, 1980$]$. 
TYPES OF SEAS DATA

\section{Environmental Data}

The Environmental data base contains information on the release and control of a comprehensive range of environmental pollutants associated with industrial activity throughout the economy. Detailed information is provided on each pollutant released to air, water, or land by energy and manufacturing industries, residential and commercial fuel combustion, and transportation activities. These data relate amounts of pollution to economic activity and are called pollution or residual coefficients. In addition, information concerning pollution control standards is provided for each pollutant, on an industry or process-specific basis, as appropriate. These data describe air and water pollutants as well as various toxic substances and trace elements released to air and water. Data are also included concerning numerous types of solid wastes, including radioactive wastes, which are released to air or water.

In addition, other environmental information is provided for various industries and processes including land use, water use (including water consumption) and several indices of occupational hazard (e.g., deaths, injuries) associated with various activities. Further, the data base contains information on the production of secondary residuals, such as scrubber sludge, that are produced by environmental control processes. 
An important characteristic of the environmental data base is that the data have been disaggregated to that level of detail necessary to reflect significant differences in the polluting characteristics of alternative manufacturing processes. For example, different data are provided for electric arc and open hearth steel production. In the nuclear fuel cycle, separate environmental data are provided for surface and underground uranium mining, for milling, for enrichment, etc.

The environmental data base is also designed to store information on regional variations in the pollution characteristics of various industries. Thus, surface coal mining in Pennsylvania is characterized by different pollution releases than coal mining in Wyoming. In addition, different regulatory standards imposed in different states are included in the data base. Capital and Operating Cost Data

These data bases provide detailed information on the capital and operating expenditures associated with industrial efforts to control pollution. It also contains information on the unit capital expenditures required to construct various energy facilities. As with the environmental data bases, energy cost data are provided in great detail for each phase of an energy fuel cycle, and for alternative processes in each phase of a fuel cycle. 


\section{Regionalization Data}

The SEAS model uses four different procedures to regionalize economic activity. Each method produces sets of shares indicating the fractions of particular economic activities occurring in individual regions. Most shares are developed at the county level and aggregated for larger regions.

Many non-energy industrial sectors are regionalized based on OBERS* regional forecasts for economic activity at the 2-digit SIC level. The OBERS forecasts are primarily based on trend extensions of regional activity compared with national activity. Specific future shares are contained in SEAS for selected industries in which significant national shifts are anticipated or for which environmental factors are especially significant. These shares have been developed in detailed industrial studies of the specific industries of concern. In addition, these shares may vary from one scenario to another. Sectors include petroleum refining and pulp and paper. For certain energy sectors there are good data on the location and capacity of future plants. These files allow for scenariodependent siting of facilities by proceeding down a list of anticipated plants until the energy demand is met. This method is used for

*OBERS forecasts were prepared by the U.S. Department of Commerce Social \& Economic Statistics Administration,. Bureau of Economic Analysis, Regional Economic Analysis Division and the U.S. Department of Agriculture, Economic Research Service, Natural Resources Economics Division for the U.S. Water Resources Council, April 1974. 
activities such as coal gasification and liquefaction. For certain sectors SEAS contains additional information on resource availability (coal reserves), independent data bases (MFBI and FPC* files) and planned or announced siting data (electric utility and coal mine openings). The three special energy modules were developed to use these data. These modules regionalize various types of electricity generation, industrial combustion, and coal mining activity. Additional Technological and Economic Factors

The three data sections mentioned previously describe the major parts of the comprehensive SEAS data base. Examples of additional, miscellaneous data which are included in the SEAS data base are soil loss data for agricultural land use, compliance data and schedules for pollution standards, ESECA mandated conversions from gas and oil to coal combustion, retirement data on electric utility plants, energy losses in various stages of the energy fuel cycle, and information on interindustry transactions reflecting material substitutions over time. The latter data are provided on anticipated technological changes from one process to another within an industry. They also reflect changes in consumption and transportation patterns. SEAS also contains information on the utilization of advanced energy technologies beyond that given by MEFS. For example, the solar

\footnotetext{
*MFBI and FPC stand for Major Fuel Burning Installations and Federal Power Commission, respectively.
} 
utilization specified by MEFS will be allocated in SEAS among thirtyfive solar technologies. All of these sets of data can be modified by the user, but specific values are stored in the data base for use as default values.

SELECTED SOURCES AND EVALUATION OF RESIDUAL COEFFICIENT DATA

Data on air and water pollutant discharges and assoctated environmental standards are for the most part entered into SEAS on an industry specific basis, although in some cases specific pollutants are studied across all industries. The following sections appraise various aspects of selected data bases, indicating areas where updates have recently been performed or are expected to be performed in the future. Additional information on detailed data sources can be found in the Bibliography for SEAS National Level Residual Coefficients [Stokes, 1979].

\section{Air Pollutants}

Criteria air pollutants overall are among the most complete and well-validated data in the model. Major data sources include AP-42 [Compilation of Air Pollution Emission Factors, 1979], the Major Fue1 Burning Installation (MFBI) tape and Federal Power Commission (FPC) tape. The 1975 emissions have been compared with National Emissions Data System (NEDS) data. Discrepancies were accounted for in all areas except transportation.

Trace element emissions data are taken from EPA documents measuring emissions factors for specific industries. The noncombustion releases of heavy metals and other trace releases to the 
atmosphere constitute one area where additional work is planned. Further work is also anticipated in the area of fine or respirable particulates. Another potential area for increased data development is releases to air of toxic organic chemicals. Water Poilutants

The primary data source for conventional point-source water pollutant discharges from industry is the series of development documents for effluent limitations guidelines published by EPA [Development Document for ..., 1972-1979]. These are released on an industry-specific bases. Assumptions of reasonable coverage for the major conventional pollutants depend on the validity of the assertion that these documents were produced for all major polluting industries. Included in these documents are data on raw waste loads of numerous metals and other trace chemicals. Few standards are proposed for many of these metals nor are data provided for reductions imposed by treatment of other pollutants in the waste streams. Water pollutant discharges from municipal wastewater treatment plants are based on detailed EPA studies.

Currently non-point source pollutant discharges are calculated for urban and agricultural runoff. There are wide discrepancies in non-point source water pollution measurements among experts in the field. Accuracy within an order of magnitude is considered reasonable. 


\section{Solid Waste}

SEAS contains secondary solid waste data for air pollution (particulates and $\mathrm{SO}_{\mathrm{x}}$ ), industrial wastewater treatment sludges and other industrial sludges. Air pollution data is based on the amount of certain pollutants removed from gaseous wastes; industrial wastewater treatment sludges is based on liquid wastes.

Other solid waste data include oil shale tallings and coal mining wastes. 
Adler, David and Dossani, Nazir. SEAS Documentation: The Energy Investment Feedback Module. Prepared for The MITRE Corporation by CONSAD Research Corporation. October 8, 1979.

Annual Environmental Analysis Report: A Preliminary Environmental Analysis of Energy Technologies Using the Assumptions of the National Energy Plan. Draft. The MITRE Corporation. September 1977.

Annual Environmental Analysis Report II (AEARII). Draft MTR-79W00284. The MITRE Corporation. December 1979.

Almon, Clopper et al. 1985: Interindustry Forecasts of the American Economy. D.C. Health and Company. 1974 .

Anderson, Robert E. Description of the Functions of and Options for All SEAS Reports. Control Data Corporation, Professional Services Division. December 15, 1978.

Bodden, Martha; Borko, Beth; Conner, William; Wolfinger, Thomas. Taxonomy Manual and User's Guide for SEAS Environmental Residuals. WP-80W00246. The MITRE Corporation. April 1980.

Carlson, Akerman, Schiffman. Scenario Development and Project Assumptions. WP-80WUU636. The MITRE Corporation. August 1980.

Compilation of Air Pollution Emission Factors. AP-42, Supplement 9 (updated regularly). U.S. Environmental Protection Agency. July 1979.

Development Document for Proposed Effluent Limit Guidelines and Standards for the Water Pollution Point Source Category. U.S. Environmental Protection Agency, Effluent Guidelines Division, EPA/440/1-**/***, $1972-1979$.

Draft Environmental Outlook 1980. Prepared by the Strategic Analysis Group, Office of Research and Development, U.S. Environmental Protection Agency. EPA 600/8-80-003. Draft. December 1979.

Environmental Trends and Impacts of National Energy Plan II. MTR-79W00225. The MITRE Corporation. 1979.

Gerson, Jeff; Doggett, Ralph; O'Farrel1, Mary. A Review and Evaluation of the INSIDE Module of SEAS. Prepared for The MITRE Corporation by International Research and Technology Corporation. October 19, 1979. 
REFERENCES (Continued)

Gerson, Jeffrey et al. Environmental Residual Trends in the Ohio River Basin. TR-212-005. International Research and Technology, Inc. April 1980.

Hand, Mary Ann. SEAS Training Session on Electric Utilities Model, WP-79W00617, Volume II. The MITRE Corporation. November 1979.

Hand, Mary Ann. SEAS Training Session on Regionalization, WP-79W00617, Volume IV. The MITRE Corporation. December 1979.

House, Peter. Trading off Environment, Economics, and Energy--A Case Study of EPA's Strategic Environmental Assessment System (SEAS). Lexington Books, Lexington, Mass. 1977.

Lawrence, Andy et al. Environmental Impact Assessment of the Proposed Standby Rationing Plan. WP-12987. The MITRE Corporation. April 1978.

McBrien, Stephen; Stokes, Betsy; Wilson, Marcia; Wolfinger, Thomas. Guidance for Interpretation of Projections from the May 1980 SEAS Reference System, WP-80W00368. The MITRE Corporation. June 1980.

Metzger, Carole. Strategic Environmental Assessment System Names and Definitions Manual. Prepared for U.S. Environmental Protection Agency and U.S. Department of Energy by Control Data Corporation. May 1980.

Metzger, Carole. Strategic Environmental Assessment System Scenario Run Control Procedures Manua1. Control Data Corporation. Draft. June 1980.

The MITRE Corporation. Environmental Data for Energy Technology Policy Analysis--Volume I: Summary. M78-74. The MITRE Corporation, CONSAD Research Corporation, and International Research and Technology Corporation. December 1978.

National Environmental Impact Projection No. 1. MTR-7905. The MITRE Corporation, CONSAD Research Corporation, Control Data Corporation, and International Research and Technology. December 1978 .

National Environmental Impact Projection II. Draft MTR-79W00118. The MITRE Corporation. March $1980^{\circ}$ 
Placet, Marylynn and Cooper, Donald. The Energy System Network Simulator (ESNS) - Application Guide, Volume I. Prepared for The MITRE Corporation by International Research and Technology Corporation. Draft. March 1979.

Preston, Edward. Introduction to the Industrial Fuel Use Module of SEAS, WP-79W00617, Volume V. The MITRE Corporation. March $\overline{1980}$.

Shapanka, Adele. Transportation Energy Module (TRANS) - Application Guide, Volume I. Prepared for The MITRE Corporation by International Research and Technology Corporation. Draft. March 1979.

Stokes, Betsy; Cumiskey, Patricia; and Hand, Mary Ann. Bibliography for SEAS National Level Residual Coefficients. WP-79w00787. The MITRE Corporation. November 1979.

Tawari, Prekimi and Hutchison, Roberta. Introduction to the Residual Generation Module of SEAS, WP-79w00617, Volume IX. The MITRE Corporation. March 1980.

TenEyck, Francine; Porterfield, Lisa; Rebibo, Kathy. A Guide to SEAS Documentation, MTR-79W00355. The MITRE Corporation. January 1980.

Weiss, Andrea; Placet, Marylynn; McBrien, Stephen. Documentation of Electric Utilities Module in SEAS for the Second Regional Issue Identification and Assessment (RIIA-2), WP-80W00027. The MITRE Corporation. June 1980.

Weygendt, William and Bernstein, Alan. SEAS Training Session On Coal Mining Mode1, WP-79W00617, Volume III. The MITRE Corporation and CONSAD Research Corporation. November 1979. 
THIS PAGE

\section{WAS INTENTIONALLY LEFT BLANK}




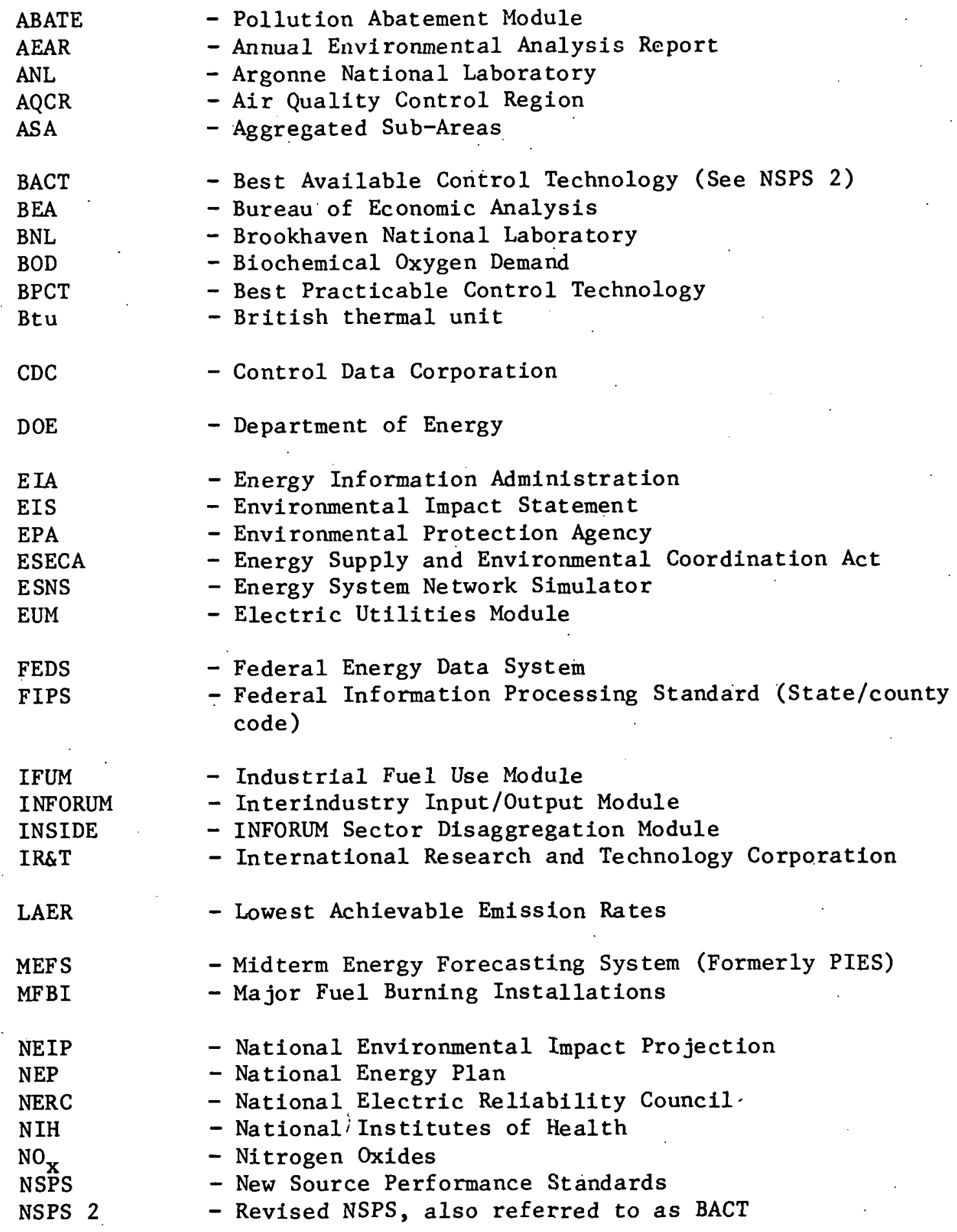




$\begin{array}{ll}\text { OBERS } & \text { - Office of Business \& Economic Research } \\ \text { ORNL } & \text { - Oak Ridge National Laboratory } \\ \text { ORBES } & \text { - Ohio River Basin Energy Study } \\ \text { OTI } & \text { - Office of Technology Impacts (part of DOE) } \\ \text { PIES } & \text { - Project Independence Evaluation System (now } \\ & \text { called MEFS) } \\ \text { RESGEN } & \text { - Residuals Generation Module } \\ \text { RIIA } & \text { - Regional Issues Identification Assessment } \\ \text { SEAS } & - \text { Strategic Environmental Assessment System } \\ \text { SERI } & \text { - Solar Energy Research Institute } \\ \text { SIC } & \text { - Standard Industries Classification } \\ \text { SIP } & - \text { State Implementation Plan } \\ \text { SMSA } & - \text { Standard Metropolitan Statistical Areas } \\ \text { SOX } & - \text { Sulfur Oxides } \\ \text { TASE } & - \text { Technology Assessment of Solar Energy } \\ \text { TDS } & - \text { Total Dissolved Solids } \\ \text { TSP } & - \text { Total Suspended Particulates } \\ \text { TSS } & - \text { Total Suspended Solids }\end{array}$


$\operatorname{Lim} 5$ Reetyk Rerico 